This is the author's accepted manuscript of a forthcoming article in the journal Comedy Studies.

\title{
Brexit Tricksters and the Reconstruction of Taboo. Populism, Irony and Satire in Post-Referendum Britain
}

\author{
Simon Weaver \\ Brunel University London
}

\begin{abstract}
This paper examines the role of irony and satire in public discourse on Brexit. It is argued that pro-Brexit discourse is structurally and textually ironic, that this irony has a significant relationship with taboo and transgression, and that this has implications for the analysis of Brexit. Building on this, the article shows that an analysis of Brexit discourse must take account of Brexit irony and that this task is specifically aided by insight from critical humour studies. Alongside this, the article argues that some comedians, through some uses of satire, are uniquely able to criticise Brexit discourse in ways that are not open to 'serious' political commentators. The article uses political discourse from Nigel Farage and Michael Gove, and comedy from Last Week Tonight with John Oliver, to highlight these points.
\end{abstract}

Keywords Brexit; comedy; irony; John Oliver; populism; satire; racism; xenophobia

\section{Introduction}

In a recent documentary for Channel 4, Grayson Perry attempted to capture the identity of European Union (EU) leave and remain supporters. Early in the show, Perry talked with leave supporters in Boston, the area of the UK with the highest leave vote by percentage. A participant named Yvonne explained her reasons for wanting to leave the EU: 
This is the author's accepted manuscript of a forthcoming article in the journal Comedy Studies.

In a way, I just feel that England can stand on its own two feet. British Isles, we've got a lot to offer. We stood on our own two feet years ago, when we had the Second World War and I feel that um, we will go forward in great numbers [...]. There was a volume of them came all at once. They didn't just trickle in, they came all at once. And I think that's what shocked the whole of the town and the area, was this influx of varying nationalities. And they felt that the town was being taken off them (Perry 2017).

Yvonne's comments encompass a number of the themes of leave discourse - an ambiguous mix of English and British nationalism, culturalism and cultural protectionism, localism, postcolonial anxiety and/or nostalgia, anti-globalism, and a denial or rejection of interconnectivity and interdependence, both past and present. What is also present is a 'reconstructed' antiimmigrant sentiment that is not simply xenophobic. Yvonne demonstrates that it is quite literally a description that relies on liquidity or ambiguity to paint a picture of mass migration as problematic. Perry comments on the irony of the leave camp in Boston, where this sentiment is expressed concurrent with farming in the area that relies heavily on migrant labour for its very existence. This article focuses on irony further as a key analytic concept for critiquing Brexit discourse ${ }^{1}$.

Perry's example highlights one of the 'situational ironies' of Brexit, where a widely accepted binary discourse on the effect of EU migration appears incongruous, incoherent or partial in relation to aspects of the situation being described (for example, in Yvonne's description, migrants play no role in revitalising Boston). It is shown throughout the article that

\footnotetext{
${ }^{1}$ Henceforth, 'pro-Brexit discourse' will be referred to as 'Brexit discourse'. It is beyond the scope of this paper to detail ironies in Remain discourse and they are not discussed. Pro-Brexit discourse is a broad concept that encompasses a number of forms of argumentation that are pro-Brexit. Moore and Ramsay (2017: 5) identify six key themes in analysis of media coverage of the EU referendum that can be used as a guide. They are 'the economy, immigration, sovereignty, dishonesty, fear, and the 'Establishment' (2017: 5).
} 
This is the author's accepted manuscript of a forthcoming article in the journal Comedy Studies.

there are also 'textual' or 'postmodern' ironies in Brexit discourse that work to hide broader situational ironies. Specifically, public and political discourse on Brexit contains irony that works to express taboo and transgression in relation to racialization, racism and xenophobia. ${ }^{2}$ The ironic or ambiguous component of much Brexit discourse functions to describe the unknown as positive and to circumvent connections with often taboo discourses of racism and xenophobia. These connections seem very easy to identify yet are befuddled by the irony. The irony of Brexit is examined through the mythic figure of the trickster. As a discursive strategy, trickster tactics are significant in Brexit discourse as a method for constructing ironic transgression that has populist appeal, and for constructing 'new' discursive taboos aimed at quieting remain supporters. Such discursive strategies appear postmodern in style (Lyotard, 1994: xxiii).

Because of the constitutive irony of Brexit discourse, some uses of satire are uniquely able to criticise Brexit discourse in a manner not available to serious political commentators. Comic and satiric responses to Brexit are predominantly from comedians that supported the remain campaign or who are heavily critical of Brexit politicians and supporters. Using rhetorical discourse analysis (see Weaver [2015] for a full outline of this methodology), and drawing on a purposive sample from John Oliver's US comedy show Last Week Tonight with John Oliver, the satiric devices used to unpack Brexit irony are highlighted. Brexit has been mentioned five times on Last Week Tonight with John Oliver. An exemplar with regard to the satiric unpacking of irony. the comedy highlights Brexit tropes and appeals to realism, performing in a more modernist style that attempts to 'speak truth to power' and assert the rational.

\footnotetext{
2 'Taboo' is defined simply as the breaking of social custom. Taboo discourse is the language of taboo - that which presents positions that are generally considered to be taboo. In relation to racialisation, racism and xenophobia, Brexit discourse offers a reconfiguration of 'acceptable' discourse. 'Transgression' is defined here as discursive boundary crossing - the social processes, or discursive events, by which taboos are shifted.
} 
This is the author's accepted manuscript of a forthcoming article in the journal Comedy Studies.

Although there is documented evidence of racialisation and racism affecting Eastern European migrants before the EU referendum of $23^{\text {rd }}$ June 2016 (Fox, Moroşanu and Szilassy, 2012: 680), there was a post-referendum spike in reports of hate crime directed at all ethnic minority groups (Fox 2017). Adam Lusher (2016) in The Independent reports on a number of racist and fascistic expressions that followed the EU referendum, which included “[c]omparisons with 1930s Nazi Germany and a crowd striding through a London street chanting: 'First we'll get the Poles out, then the gays!'” (Lusher 201). I argue that examples of race hate that follow the EU referendum are rendered permissible by a discourse on Brexit and racism that contains an amount of liquidity, that befuddles critique and attempts 'acceptability' (Bauman 2000: 168; Weaver 2011: 64-64). Brexit discourse is ambiguous, unstable, taboo and not taboo, contains polarisations, yet articulates older themes from cultural racism and antiimmigrant prejudice (Weaver 2011: 97-117).

The aims of the article are addressed first through a discussion of the context of Brexit as one framed by populism and globalisation, before elaborating on the analytic usefulness of the concepts of tricksters and taboo for understanding Brexit discourse. Then I examine two examples of Leave campaigning, one from Conservative Member of Parliament (MP) Michael Gove, and one from United Kingdom Independence Party (UKIP) Member of the European Parliament (MEP) Nigel Farage, highlighting the irony in both, before detailing the satiric response from John Oliver.

\section{Populism, Globalisation and Brexit}

Brexit has been regularly referred to as a populism (Thompson 2016). Brexit discourse matches several of the components of populism outlined by Taggart (2000: 2-3). These are: 1) "ambivalence about politics, especially representative politics. Politics [...] [as] messy and 
This is the author's accepted manuscript of a forthcoming article in the journal Comedy Studies.

corrupting" (ibid.: 3); 2) identifying "with an idealized version of its chosen people, and [...] a similarly idealized landscape" (ibid.); 3) "an ideology lacking core values" (ibid.: 2); 4) "a powerful reaction to a sense of extreme crisis" (ibid.); and 5) "containing fundamental dilemmas that make it self-limiting" (ibid.). These tendencies appear to varying degrees in Brexit discourse and some will be addressed in more detail in this paper. Point 2, on an idealized people and landscape, is best addressed through a discussion of globalisation and Brexit.

Responses to globalisation feature heavily in this populism, where there is a polarisation of debate on globalisation, and discussion of the haves and the have-nots of the global world, of who does and does not benefit. The character of discussion fits the dichotomy of a "utopia/dystopia of globalisation" (Featherstone 2013: 67, original emphasis) that is prominent in Zygmunt Bauman's Liquid Modernity (Bauman 2000: 1). In Bauman's description, there are those who gain - the tourist, and the rich inside the gated community, and those that suffer - the 'other', the poor, the migrant. The populist discourse that surrounds Brexit focuses on two of these tropes - the 'other' as migrant and 'us' as the poor, or the becoming poor - and sees the construction of the migrant as scapegoat for the latter concepts. The breaking and reconstruction of taboo discourse on the 'other' is fundamental argumentation in this process. Featherstone describes the process of globalisation as one that is reaching saturation point: “There is nowhere for this process to go, but to turn back in on itself" (Featherstone 2013: 71). This signals a point of crisis for globalisation that is analogous to the Brexit sentiment. The leave vote was in many ways a call for contraction, yet this is a self-limiting component of its populism because the discourse also contains the call for Britain to look globally in moving away from Europe.

Articulations of social class have been used to describe the populism of the Brexit vote as positive. Brendan O'Neill did so in The Spectator on $2^{\text {nd }}$ July 2016: 
This is the author's accepted manuscript of a forthcoming article in the journal Comedy Studies.

\section{Brexit voters are not thick, not racist: just poor}

By forcing Britain to quit the EU they have given a bloody nose to an elite that views them with contempt.

This rebellion wasn't caused by racism or a paroxysm of infantile anger. It was considered. The workers spied an opportunity to take the elite that despises them down a peg or two and they seized it. They asserted their power, and in the process, blimey: they changed the world. (O’Neill 2016, original bold)

O’Neill's commentary points to a predominately working class nationalism as something that has been stigmatized and repressed, especially by the political Left, where there have been relative successes for anti-racism, with anti-immigrant sentiment increasingly taboo. Such nationalism is sceptical of multiculturalism and European free movement. That said, the Brexit vote as a populist expression driven by working class anger, particularly working class northern anger, has been described as a partial analysis by Dorling:

Contrary to popular belief, $52 \%$ of people who voted Leave in the EU referendum lived in the southern half of England, and 59\% were in the middle classes, while the proportion of Leave voters in the lowest two social classes was just $24 \%$ [...]. Most people younger than 50 who voted, voted to remain. But rather than blame the older generation, their ire should instead be directed squarely at all the post 1979 UK governments that have allowed economic inequalities to rise so high. (Dorling 2016)

The middle classes of over fifty years of age are consistently more likely to vote than younger voters and were significant in the Brexit decision. The inclusion of a middle class vote highlights the expansive populist appeal of the discourse. Despite the seemingly broad class 
This is the author's accepted manuscript of a forthcoming article in the journal Comedy Studies.

construction of the Brexit decision, and the appeal of Brexit to those of all classes, in some instances this appeal translates directly into an argument over the nature of taboo and the boundaries of discourse in relation to the 'other' that are mediated through but not reducible to generational experience and class position - dichotomies that have significantly affected comedy taste. It is therefore reasonable to assume that positions on Brexit are expressed very well through comedy.

\section{Tricksters, Taboo and the EU Referendum}

The trickster is a figure from myth, documented in anthropology, and a trope that directly relates to the crossing of social and/or discursive boundaries, and creative activity (Turner, 1987: 168-169). There are instances where such figures connect with comedy although they are not inherently comic figures. They are more accurately described as brokers of change or ambiguity. The trickster will be used as an analytic tool to explain some pro-Brexit discourse, particularly the use of irony as a trope in political discourse, which is employed to reshape consensus and taboo, assert populist themes, and attack perceived inertia.

The trickster is a figure that often accompanies changing social realities and the ambiguity of periods of social change. The idea of liminality is used by Victor Turner (1974: 58, 1982: 32-33, 1987: 107), who draws on van Gennep's conceptualisation of rites of passage, to describe the unstable part of change processes where taboos can be altered or erased and new norms created. This, for Turner, is described as "anti-structure" (ibid.). This is an apposite nomenclature for the UK's EU referendum and Brexit period. Turner describes the liminal as a period where "subjects pass through a period of ambiguity, a sort of social limbo which has few $[\ldots]$ of the attributes of either the preceding or subsequent profane $[\ldots]$ cultural states" (Turner 1974: 57). The liminoid is added by Turner (1974: 58) as a revised concept for modern society and one that moves away from the structural functionalism of the earlier idea of 
This is the author's accepted manuscript of a forthcoming article in the journal Comedy Studies.

liminality, towards an inclusion of individuality (cf. ibid.: 83). Although trickster activity is concerned with social change in liminoid or ambiguous social space, it is important to note that the direction of changes that can occur through trickster activity can be both conservative and/or revolutionary. They are thus perfectly suited for populist agitation. Elements of the leave campaign and surrounding Brexit discourse take on the characteristics of trickster discourse and appear postmodern.

The trickster is described as a character that interrupts social order through the creation of disruption or chaos that then creates the possibility for new social realities (cf. Hyde 2008: 1; Mackin 2002: 191; Vizenor 1988: x). Mackin (2002) describes tricksters "as outlaws who manipulate meta-level fantasies and who are then in a position to realign the social world" (ibid.: 201). In the populism of Brexit, fantasies of the nation and control are engaged to create new political realities. The Brexit trickster is one that emerges under the conditions of free movement in the EU but seeks to reassert the boundary. Although Hyde claims that the trickster as traveller is " "on the road' [...] the lord of in-between [...] he is the spirit of the road at dusk, the one that runs from one town to another and belongs to neither" (2008: 6), the Brexit trickster is one that wishes to halt this movement, control the road, and place the furtive trickster on the other side of the border.

\section{Brexit Politics and Satire: Data Analysis}

This section analyses two instances of leave campaigning and two comedic responses to it. The sample is strictly purposive and thus no claim of representativeness is made here. The selection of political campaigning is made on the basis of the two examples being ironic, taboo transgression. The comic responses are exemplars of political satire designed to unpack such irony. The first instance of campaigning is from the Conservative Member of Parliament and leave campaigner, Michael Gove. This is responded to by the comedian John Oliver, on his US 
This is the author's accepted manuscript of a forthcoming article in the journal Comedy Studies.

Home Box Office show Last Week Tonight with John Oliver. The second example of leave campaigning is from Nigel Farage, the then leader of UKIP and a key figure in the 'leave.EU' campaign. Again, the comedic response is from John Oliver on Last Week Tonight with John Oliver.

\section{Michael Gove and the Irony of Post-Expertise}

In a Sky News interview on $3^{\text {rd }}$ June 2016, Michael Gove was questioned by the Sky journalist Faisal Islam on the broad range of expert and organisational disagreement with Gove's economic position on the benefits of leaving the EU. Gove employs in the interview an antielitist, populist discourse. He positions himself as representing 'the people' with organisations and experts against Brexit, and indeed Faisal Islam himself, as representation of the elites. He urges the British people to "take back control of our destiny from those organisations that are distant, unaccountable and elitist" (Gove and Islam 2016. Emphasis added). Gove continues:

Michael Gove: I think the people in this country have had enough, of experts, with uh organisations...

Faisal Islam: Had enough of experts?

M.G.: from acronyms, saying, saying...

F.I.: People in this country have had enough of experts? What do you mean by that?

M.G.: from organisations with acronyms, saying they know what is best and getting it consistently wrong. (Gove and Islam 2016)

Gove's discourse relies on a rhetoric of populism, of the people verses, importantly, elitist experts. To return to Taggart's definition of populism, we see the discourse contains “ambivalence about politics [...] [as] corrupting" (Taggart 2000: 3), "an idealized version of its chosen people" (ibid.), "a powerful reaction to a sense of extreme crisis" (ibid.: 2), and less 
This is the author's accepted manuscript of a forthcoming article in the journal Comedy Studies.

explicitly "fundamental dilemmas that make it self-limiting" (ibid.). The final point will be expanded shortly. The rhetorical device of argumentum ad hominem is obvious because it is the dubious character of the experts that is attacked, their distance and unaccountability, rather than the content of their argument. The argument follows that they are wrong because of their privileged social position and because they benefit from the EU, rather than because of any counterargument offered by Gove or the leave campaign. Where evidence is employed by Gove in the interview, it relies on the trope of anecdote, with a brief story about his father's business that is analogised to explain economic problems across the country. The discourse expressed matches Jean-François Lyotard's The Postmodern Condition (1979), which specifies the end of credulity for grand narratives in postmodernity and the proliferation of language games of competing truth claims. The experts of globalisation are increasingly called into question. The upset of any certainty of ideas and the proposed validation of populist interpretations of reality fit well with the zeitgeist of contemporary politics, where 'fake news' and 'alternative facts' act to establish the 'truth' of the 'theft' enacted by the elites.

But none of this can be read literally. Gove is employing irony in the interview, which is another postmodern theme (cf. Flieger 1991: 21). Sometimes the irony of postmodernity is described as playful but it can also be described as coupled with the emergence of social ambiguity, incongruity or dichotomy. It allows for trickster tactics in ambiguous social spaces. Bennett (2016) outlines a concept of blank irony that assists with the analysis of Gove's discourse. Bennett says that "[t]he irony matters... because of what (if we take it literally) it is about" (ibid.: 261, original emphasis). It is unlikely that Gove is asserting that society ignores expert opinion per se, or even economists in particular, nor is it the acronyms of organisations that are especially problematic. Indeed, a literal reading and enactment of Gove's comments would have major consequences for the continuation of meaningful social life or society in $21^{\text {st }}$ Century Britain. If Gove is suggesting that 'the people' have had enough 
This is the author's accepted manuscript of a forthcoming article in the journal Comedy Studies.

of experts, he surely cannot endorse this literally, which might imply an ignoring of human knowledge and a descent into the absurd. Emile Durkheim's (1997: 111) concept of organic solidarity can be evoked here to imagine the literal interpretation of Gove's rhetoric, and to assert quite strongly that nobody, anywhere, has literally had enough of experts. What does irony 'do' in this example? To apply Bennett, "what is being said is perhaps not meant - we cannot be sure" (ibid.), and thus Gove is able to create a populist rhetoric and appeal, simultaneously render the literal interpretation of his message absurd if followed (and a naïve interpretation - it is, of course, the sentiment that is important), and make the critique of his message a symptom of the very (elitist) activity and problem he is describing. Such play with ambiguity is certainly tricksteresque. The liminoid space of the referendum campaign encourages a populist expression in which accepted realities can be dismissed in an ambiguous, ironic discourse that neither appears to meet any criteria of serious evaluation, nor in fact is required to do so.

\section{Speaking Truth to Populism}

Michael Gove is responded to by the comedian John Oliver, who offers a pre-referendum attempt to convince the British to vote to remain, which was not aired in the UK by Sky Television until after the referendum because it was deemed to be politically unbalanced and thus could have been judged to be in breach of broadcast laws during election time:

John Oliver: There's also overwhelming consensus about the damage Britain could do to its economy by leaving. Reports by groups like the British Treasury, the Bank of England, the IMF, the OECD, the National Institute of Economic and Social Research, Price Waterhouse Coopers, Oxford Economics, and the Centre for Economic Performance have all predicted that leaving would have a negative effect on the British GDP. And the proBrexit camp's response to that has not been great. 
This is the author's accepted manuscript of a forthcoming article in the journal Comedy Studies.

[Plays clip from the Gove/Islam interview that is reproduced above]

John Oliver: Yes, fuck these eggheads with their studies and degrees, I get my economic forecasts from Clever Otis, the GDP predicting horse.

[A picture of a horse with large teeth, wearing glasses with a pencil behind its ear, is shown in the caption box] (Oliver 2016)

Oliver employs comic tropes in critique of Gove's irony. This is, importantly, something that is not directly available to Islam in the 'serious' political interview format. Oliver clearly acts satirically. In the first part of the extract, Oliver simply lists that many organisations predict that Britain's gross domestic product (GDP) will suffer on leaving the EU. This employs the tropes of catalogue and repetition (Berger 1995: 54-55), which are juxtaposed with Gove's comments to highlight the perceived fallacy of the latter. After the subtle juxtaposition, Oliver uses ridicule and absurdity toward Gove through the presentation of 'Clever Otis, the GDP predicting horse'. The ridicule is constructed through the use of an anthropomorphic rhetorical device or image - one that gives human, in this case intellectual, characteristics to an animal. This serves to align Gove's economic expertise with the absurd. Through comedy, this is achievable in a manner that is not possible in serious political journalism, and thus it is quickly able to disconnect Gove's statement from truth and reassert modern principles of rationality, accuracy and truth.

\section{Nigel Farage, UKIP and Liquid Racism}

UKIP are a party that draw heavily on anti-immigrant discourse, yet they do so with an amount of ambiguity and impunity. Their discourse is attacked for containing racism but this is 
This is the author's accepted manuscript of a forthcoming article in the journal Comedy Studies.

constantly denied. In an interview for Channel 4 News on $20^{\text {th }}$ June 2016 , Nigel Farage is questioned by Krishnan Guru-Murphy on a controversial 'leave.UK' campaign poster that depicts a crowd of Syrian refugees:

Krishnan Guru-Murphy: Your poster has been taken by many people to be deeply offensive, upsetting, racist, anti-Muslim. Would you like to apologise to them tonight?

Nigel Farage: Well, I issued a very similar poster to that two months before, uh, with very little debate, uh. The problem with the poster wasn't the image, after all, it appeared on all of our front-page newspapers, and the strapline 'the EU has failed us all', you know, what I'm saying is that what Mrs Merkel did last year has led to a huge crisis inside the European Union. Add that to the Euro crisis and what on earth are we doing there as members of this failing union?

K.G.-M.: Okay so no apology...

N.F.: The problem was of course...

K.G.-M.: Okay so do you see?

N.F.: Well, hang on, hang on...

K.G.-M.: No, let me finish the point. Do you see that, why people would regard this as xenophobic and racist? I mean, there you are, in front of a poster full of brown faces on the move, coming into Europe, with a big banner headline saying 'breaking point'. The only white face has been obscured by text. Many people took that as deeply offensive, and I ask you again, do you want to take this opportunity to say sorry? 
This is the author's accepted manuscript of a forthcoming article in the journal Comedy Studies.

N.F.: Well, the Schengen Zone is at breaking point. That is undeniable. Uh the picture is true, it wasn't doctored. What I apologise for is the timing. You know, some people have, have been given the impression that somehow we issued this poster after the appalling murder in the street that took place, we did not.

(Farage and Guru-Murphy 2016. Emphasis added)

UKIP draw on anti-immigrant discourse that is layered with ambiguity. Ford, Goodwin and Cutts (2012) explain how voters are attracted to UKIP from across the middle and working classes for a combination of Euroscepticism, xenophobia and Islamophobia. They argue the middle classes frame their interest in terms of Euroscepticism whereas working class support is framed in relation to xenophobia and Islamophobia (ibid.: 1). Evans and Mellon (2016) argue that UKIP have gained votes from the Labour Party due to the latter's "move to the 'liberal consensus' on the EU and immigration" (ibid.: 464). This points to UKIP support as symptomatic of a dystopic perception of globalisation. Adding to this analysis, my concept of liquid racism (cf. Weaver 2011: 63-64) - a racism of ambiguous cultural signs that combine older racisms, political and social issues that are not expressions of racism per se, entrenched socio-discursive positing, and an overall ambiguity of racist intent and meaning - can be used to explain some of the slipperiness of the discourse of Farage, UKIP and much of the leave campaign. Liquidity is encouraged by sophisticated forms of coding and the addition of ambiguity or semantic layers to a text, leading to the inability to pin down what is really meant. This is also an ironic endeavour. But if we look at what the irony is actually about, the sentiment remains anti-immigrant. There is an attempt to transgress taboo and redraw boundaries in such ironic trickster activity, which asserts anti-immigrant discourse as not taboo.

Guru-Murphy attempts to build anti-racist critique with reference to colour racism and to the literal. The poster shows only brown faces. It is connected with other ambiguous statements 
This is the author's accepted manuscript of a forthcoming article in the journal Comedy Studies.

by Farage. Finally, later in the interview, a question is posed on how many people in the poster made it to Britain. This appeal to the literal, as critique, fails to some extent because it does not fully describe the content of the racism present in the poster - one that obsesses with crowds of 'others', borders and movement.

Farage's defence of the poster draws on ambiguity and is ironic in tone. The defence is slippery or liquid in construction. In the first part of the answer, Farage suggests that it is the timing of the poster that was unfortunate. There is an appeal to the temporal (discussed below) in distancing the poster from the murder of Jo Cox MP. Farage does not want the poster to be seen as in anyway a response to the murder and the comment that it was released ninety minutes before is an attempt to generate distraction and ambiguity on the content of the poster, which is the focus of questioning. In defending that content, Farage attempts to fix its interpretation by saying the 'the picture is true, it wasn't doctored' while simultaneously asserting the truthfulness of his interpretation of the photograph. Farage argues over the meaning of the poster and thus attempts to convince the audience by suggesting that his "coded iconic message" (Barthes 1977: 34) or connotative reading is in fact the "non-coded iconic message" (ibid.: 34) or denotive reading. We know that images are polysemic and ideological. There are obvious racist connotations in this poster. Farage acts ironically to deny this in trickster discourse that aims to redraw the boundaries of taboo.

\section{Satire and Anti-Racist critique}

John Oliver only briefly deals with the poster, describing it thus:

UKIP argue that a Brexit would enable the UK to significantly reduce immigration, preventing both EU citizens from taking British jobs and non-EU citizens from sneaking 
This is the author's accepted manuscript of a forthcoming article in the journal Comedy Studies.

in to commit terror attacks. And they have not been subtle with toxic posters like this showing lines of refugees and the headline 'Breaking Point'. (Oliver 2016)

The satire offered on the poster is not something that draws on comic tropes. However, Oliver offers a critique of UKIP and other incidents of racism involving UKIP members and candidates. This provides both an introduction and, importantly, a context:

J.O.: And at this point, you may be thinking if leaving is so universally seen as a bad idea, who the fuck is in favour of it? Well, let me introduce you to one of the leading groups backing a Brexit, the UK Independence Party, also called UKIP. Their leader is Nigel Farage [...] UKIP is known for its hardline anti-immigration views, and some of its members have engaged in outright racism. Just look at Robert Blay, a UKIP candidate for parliament who was suspended after a tabloid paper caught him saying this about a rival of Sri Lankan decent:

[Plays clip of Blay]

Michael Blay: His family's only been here since the seventies. You're not British enough to be in our parliament.

J.O.: Wow there, just hold, not British enough to be in our parliament? He's talking about a British citizen who was born in London and raised in Hampshire. How is that not British enough? Must he literally be a monocled Badger named Reginald who lives in a Shepard's Pie. Is that the bar of entry to him? (Oliver 2016)

Omitted by Oliver is that the secret interview recorded by the Daily Mirror includes Blay saying he will shoot the rival (Conservative) candidate if elected, and so expresses a violent racism. In this extract, an anthropomorphic image and an exaggeration of national stereotype 
This is the author's accepted manuscript of a forthcoming article in the journal Comedy Studies.

are used to ridicule Blay. Again, this critiques the comments by separating them from the rational, and seeks to reassert racism as unacceptable or taboo. The episode gives two other examples of UKIP candidates using racism, and a defence of one of them by Farage. Overall, the satire that Oliver develops uses a number of comic tropes that include literalness, absurdity, repartee, mimicry, repetition and ridicule (Berger 1995: 54-55). It works to significantly undermine the UKIP brand, one that is constructed through an ambiguous relationship with taboo discourses of racism and xenophobia, by showing UKIP racism and separating it from the reasonable. This does not trivialise the seriousness of the racist discourse and serves to reinforce the anti-racist critique.

\section{Conclusion}

The article examines the role of irony and satire in public discourse on Brexit. It argues that some pro-Brexit discourse is ironic, that this has implications for the analysis of Brexit, and that this irony has a relationship with often taboo discourses of anti-immigration, and allows for transgression. The analysis of Brexit discourse needs to take account of Brexit irony as the discourse attempts to describe an unknown future as positive and to circumvent connections with often taboo discourses of racism and xenophobia. The mythic figure of the trickster was introduced to aid the analysis of Brexit discourse. As a discursive strategy, trickster tactics are highlighted in Brexit discourse as a method of constructing ironic transgression that has populist appeal, and of constructing 'new' discursive taboos aimed at quieting remain supporters. Such discursive strategies are postmodern in style. The irony of pro-Brexit, antiimmigrant discourse works to transgress what is held by many to be the boundaries of taboo discourse. This image of the trickster as a policer of the boundary is both a conservative and revolutionary trickster. 
This is the author's accepted manuscript of a forthcoming article in the journal Comedy Studies.

Comedians, through some uses of satire, are uniquely able to criticise populist incongruity in ways that are not open to 'serious' political commentators. Satiric responses to Brexit discourse from John Oliver are shown to be able to deconstruct Brexit tropes and appeal to realism. This is an appeal to stability, as the comedian performs the role of highlighting absurdity. The comedian can be said to attempt performance in an Enlightenment, modernist style that 'speaks truth to power'. In terms of the implications for political communication, comic discourse may be able to achieve something that other discourse cannot. By critiquing irony as absurd through the use of other comic tropes, rather than seeking to pin down the precise meaning or actual message inside populist communication, satire is able to highlight the construction of the ironic message as formed through comic incongruity, and thus demonstrate its distance from nuanced descriptions of social reality. This highlights the continuing importance of political satire for comprehending ambiguous, populist discourse, alongside the importance of critical humour studies as a mode for deciphering contemporary populisms.

\section{References}

Barthes, Roland. 1977. "The Rhetoric of the Image.” In Image, Music, Text. London: Fontana Press, p 32-51.

Bauman, Zygmunt. 2000. Liquid Modernity. Cambridge: Polity Press.

Bee, Samantha. 2016. Full Frontal with Samantha Bee. Turner Broadcasting System (TBS), 27.06.2016, 10.30/9.30c, Series Two (directed: Paul Pennolino and Andre Allen), online at https://www.youtube.com/watch?v=9r5P1z4OWWo (accessed 06.06.2017).

Bennett, Joe. 2016. "The critical problem of cynical irony. Meaning what you say and ideologies of class and gender.” Social Semiotics 26 (3): 250-264. 
This is the author's accepted manuscript of a forthcoming article in the journal Comedy Studies.

Berger, Arthur. Asa. 1995. Blind Men and Elephants. Perspectives on Humor. New Brunswick: Transaction.

Dorling, Danny. 2016. Brexit. The decision of a divided nation. Online at http://www.dannydorling.org/?p=5568 (accessed 11.06.2017).

Durkheim, Emile. 1997. The Division of Labor in Society. New York: Free Press.

Evans, Geoffrey and Jon Mellon. 2016, "Working Class Votes and Conservative Losses. Solving the UKIP Puzzle.” Parliamentary Affairs 69 (2): 464-479.

Farage, Nigel and Krishnan Guru-Murphy. 2016. "Interview with Nigel Farage for Channel 4 News." Channel 4, 20.06.2016, 19.00, (executive producer: Andrew Epstein), online at https://www.youtube.com/watch?v=E6fbVldv_A8 (accessed 11.06.2017).

Featherstone, Mark. 2013. "Welcome to the Hotel California". Bauman and Virilio on Utopia, Dystopia and Globalisation.” In Mark Davies (ed.) Liquid Sociology. Metaphor in Zygmunt Bauman's Analysis of Modernity. Farnham: Ashgate Publications, p.67-83.

Flieger, Jerry Aline. 1991. The Purloined Punchline. Freud's Comic Theory and the Postmodern Text. Baltimore/London: John Hopkins University Press.

Ford, Robert C., Mathew J. Goodwin and David Cutts. 2012. "Strategic Eurosceptics and polite xenophobes. Support for the United Kingdom Independence Party (UKIP) in the 2009 European Parliament elections.” European Journal of Political Research 51 (2): 2014-2034. Fox, Jon E., Laura Moroşanu and Eszter Szilassy, 2012. "The Racialization of the New European Migration to the UK." Sociology 46 (4): 680-695.

Fox, Jon E. 2017. "Eastern Europeans, Brexit and Racism.” In British Sociological Association News. June 2017, online at https://www.britsoc.co.uk/about/latest-news/2017/may/easterneuropeans-brexit-and- 
This is the author's accepted manuscript of a forthcoming article in the journal Comedy Studies.

racism/?utm_source=newsletter\&utm_medium=email\&utm_campaign=may_news\&utm_ content=jon_fox (accessed on 06.06.2017).

Gove, Michael and Faisal Islam. 2016. "EU. In or Out? Interview with Michael Gove.” Sky News, 03.06.2016, Sky (editor-at-large: Adam Boulton), online at https://www.youtube.com/watch?v=GGgiGtJk7MA (accessed on31.05.2017).

Hyde, Lewis. 2008. Trickster Makes this World. How Disruptive Imagination Creates Culture. Edinburgh: Canongate.

Lusher, Adam. 2016. "Racism unleashed. True extent of the "explosion of blatant hate" that followed Brexit result revealed." In The Independent, online at http://www.independent.co.uk/news/uk/politics/brexit-racism-uk-post-referendum-racismhate-crime-eu-referendum-racism-unleashed-poland-racist-a7160786.html, (accessed on 06.06.2017).

Lyotard, Jean-François. 1994. The Postmodern Condition. A Report on Knowledge. Manchester: Manchester University Press.

Mackin, Jonna. 2002. "Trickster-outlaws and the comedy of survival.” In Graeme Harper (ed.) Comedy, Fantasy and Colonialism. London: Continuum, p.189-204.

Moore, Martin and Gordon Ramsey. 2017. UK media coverage of the 2016 EU Referendum campaign. London: The Policy Institute, Kings College London.

Oliver, John. 2016. Last Week Tonight with John Oliver. HBO, 19.06.2017, 23.00 ET, Series 4 (executive producers: John Oliver, Tim Carvell, James Taylor, Jon Thoday, Liz Stanton). O’Neill, Brendan. 2016. "Brexit voters are not thick, not racist: just poor.” In The Spectator. online at https://www.spectator.co.uk/2016/07/brexit-voters-are-not-thick-not-racist-justpoor/. 
This is the author's accepted manuscript of a forthcoming article in the journal Comedy Studies.

Perry, Grayson. 2017. Divided Britain. Swan Films production for Channel 4 Television, 29/05/2017, 21.00 (directed: Neil Crombie).

Taggart, Paul. 2000. Populism. Buckingham/Philadelphia: Open University Press.

Thompson, Grahame. 2016. "Brexit and the rise of populism." In Open Democracy UK. online at https://www.opendemocracy.net/uk/grahame-thompson/populism-biggest-winner-fromuk-referendum (accessed on 09.06.2017).

Turner, Victor. 1974. "Liminal to liminoid, in play, flow, and ritual. An essay in comparative symbology." In The Rice University Studies 60 (3): 53-92.

Turner, Victor. 1982. From Ritual to Theatre. The Human Seriousness of Play. New York: PAJ Publications.

Turner, Victor. 1987. The Anthropology of Performance. Baltimore: John Hopkins University Press.

Vizenor, Gerald. 1988. The Trickster of Liberty. Tribal Heirs to a Wild Baronage. Minneapolis: University of Minnesota Press.

Weaver, Simon. 2011. The Rhetoric of Racist Humour. US, UK and Global Race Joking. Abingdon: Routledge.

Weaver, Simon. 2015. "The Rhetoric of Disparagement Humor: An Analysis of Anti-Semitic Joking Online.” HUMOR 28 (2): 327-347. 